\title{
Causative Constructions: A Descriptive Analysis
}

\author{
Philip Manda Imoh * \\ http://dx.doi.org/10.4314/ujah.v14i2.4
}

\section{Abstract}

This study is a descriptive study of causative constructions in Bassa language. It is a language classified as belonging to the Western Kru of Benue Congo (Blench, \& Williamson, 2000:25; Crozier and Blench, 1992:32). Causative construction implies an expression where the caused event is depicted as taking place because someone does something or something happens, that is, if $x$ hadn't happened, $y$ wouldn't have happened. The process is characterized by two events such that one occurs at $t 1$ and another at $t 2$, and the occurrence of the first is responsible for the second event. Data for the study were sourced by a customized checklist, my native intuition as native speaker, and some written texts in Bassa. The work discovered that morphologically derived causative verbs could come from a verb or an adjective stem and in each case; it is characterized by transitivizing the derived verb with the resultant effect of increasing the argument by one to the basic structure and transformation of the arguments. In this case, the basic subject moves to the object position and the applied argument, that is, the causer argument becomes the subject of the derived mono-clausal structure. This work also discovered that when these processes occur, the applied subject is focalized, becomes the privileged argument and displaces the inherent subject and moves it below the predicate and the derived mono-clausal sentence from the complex sentence is economized. 


\section{Introduction}

This study is on causative constructions as it concerns Bassa language. Causativization is a universal phenomenon of language that occurs in various ways and processes. It involves two arguments where one influences the other to carry out the event implied by the predicate. That is, the event would not take place if the causer did not coerce the causee. The focus of this work is to investigate the pertinent complexities and intricacies of causativization in this language. This study will attempt to answer the questions such as: What is the syntactic position of the applied subject argument as a result of causativization? What happens to the inherent subject when this process applies? What is the nature of the derived structure after this process applies?

The Bassa people are in all the Federal Capital Councils: Kwali, Abaji, Gwagwalada, Kuje, Bwari, Municipal Kogi; Nasarawa; Niger; and Benue states. The Bassa in Kogi are found in Bassa, Dekina, Kotonkarfe, Kogi, and Ankpa Local Government Areas; Niger, in Kontagora Local Government; Nasarawa State, in Nasarawa, Kokona, Doma, and Toto Local Government Areas; in Benue, they are located at Agatu Local Government. According to 2008 census, Bassa had the population of 224,839 (National Population Commission 2008). This is highly disputable as many people believe the population of Bassa triples that figure.

Bassa language is one of the Nigerian languages that are highly under-defined or under-described compared to larger languages like Yoruba, Igbo, Hausa, Ibibio, Efik and others. Bassa language has orthographies designed by missionaries who were non- linguists for the sole purpose of translating the Bible and other Christian literatures such as the Pilgrim's Progress (authored by John Bunyan), the Way of Salvation and 
abstracts of the Bible. This, they did by devising primers to enable users of these materials to learn how to spell, read, and write. Apart from long essays written by some undergraduates and the researcher's M.A. thesis titled "Aspects of Bassa Morphology", no further scholarly works have been done on this language.

This work is purely a descriptive one and the following are methods used to source for data for this study:

i. a customized checklist is used as the primary source of generating data for this study: The researcher engaged native speakers of Bassa language to fill the checklist.

ii. The researcher, being a native speaker of the language, used his native intuitions corroborated by inputs from other native speakers.

iii. Other relevant linguistic and non-linguistic materials such as the Bassa Bible, hymns etc. were also used as a means of gathering data for this work.

iv. The researcher also observed native speakers and interacted with them to study features of morphosyntax with particular interest on causativization.

This study intends to create awareness of this fascinating morphosyntactic processes underlying the interaction of morphology and syntax, that is, the syntactic processes of causativization that is morphologically motivated in Bassa language and also to motivate further research on the language to curb its endangerment. Against this backdrop, this study aims at revealing the rich linguistic resources and make meaningful contribution to the linguistic literature, document this aspect of its structure, create an awareness of the syntactic processes of the language and revive it from its moribund state. This work is divided into four sections; section one does a general introduction to the study, section two reviews the causative literature, section three presents the data and analysis 
of causatives and it applies to Bassa language and the last segment concludes the study with a summary of the findings.

\section{Causativity: Conceptual and Theoretical Background}

Crystal (2008:70) describes causative as the phenomenon of a causal relationship between alternative versions of a sentence. He exemplifies this with a pair of sentences such as the cat killed the mouse and the mouse died. He states that the two sentences are related in that the transitive kill can be seen as a causative version of the intransitive die i.e. 'cause to die' (the cat caused the mouse to die). He further asserts that some affixes have a causative role, e.g. -ize as in domesticize (= cause to become domestic). This relationship is clearly established in the morphological structure of some languages (such as Japanese, Turkish) where an affix can systematically distinguish between non-causative and causative uses of a verb.

A causative is an expression, in which an event (the caused event) is depicted as taking place because someone does something or because something happens, that is, if $\mathrm{x}$ hadn't happened, y wouldn't have happened. The linguist, Shibatani characterizes this phenomenon as a relation between two events such that one occurs at $\mathrm{t} 1$ and another at $\mathrm{t} 2$, and the occurrence of the second event is wholly dependent on the occurrence of the first event. He further explains that, the dependency of the two events must be to the extent that it allows the speakers to entertain a counter factual inference that the caused event would not have happened at the time in question if the causing event had not happened, provided that nothing happened (Shibatani: 1976:1).

Causatives are common throughout the world's languages. The verb used in causative construction is known as a causative verb (Anyanwu 2007:18). Comrie reports that they 
are a source of great interest especially because of the important role they play in the derivational morphology of some languages, and also because of the way their analyses require complex approach combining syntax, semantics and morphology (Comrie 1985b:323). In the words of Comrie (1985b:323):

Causative, which is a valency-increasing mechanism, is used to refer to a construction derived from another basic construction. Both the basic construction and the derived construction express the same situation, but the derived one has a different subject and it is the reference of the new subject that brings about the situation described by the basic construction.

In most cases, causativity has the meaning "to cause or to make somebody do something" or to cause something to become something different" (Mutaka, 2000:177). Mutaka specifies that when it is added to intransitive verbs, the causative suffix adds a subject which functions as agent, whereas, the inherent subject is displaced and functions as the object. He exemplifies this with the following examples from Akoose and Bafut languages:

(1) a. Akəose (-ed/-t)

(i) wò̀ 'to laugh' wò̀-t 'cause to laugh'

(ii) mòd à wòstย? mwăn man he laugh +CAUS=IMPF child 'The man is making the child laugh'

b. Bafut (-sə)

(i) wǒ 'fall/fail in an interprise' wòsə 'cause to fail'

ii) sùù kì wǒ 'Suh failed (his exams)' Suh P2 fail 
(iii) tfí tfâ kì wòsə Sùu
teacher P2 fail+CAUS Suh
'The teacher caused Suh to fail (her exams)'

$\mathrm{He}$ also reports that, in some languages especially in narrow Bantu languages, the causative suffix also has the effect of changing transitive verbs to ditransitive. When it is added to a transitive verb, the agent of the transitive verb becomes the object. The causing agent then takes up the normal subject position before the verb, whereas the direct object then occurs after the real agent which now occupies the object position (Mutaka, 2000:178). This he exemplify in Akoose thus:

(2) (i) mwan à cíbé mone 'the child stole money' child he steal+PERF money

(ii) mod à cíbté mwan mone person he steal+CAUS -PERF child money 'the man made the child steal money'

In each of the cases in the foregoing causatives, the applied argument displaces the basic subject and becomes the agent and subject of the derived causative sentence. The derived subject also becomes the focus of the derived sentence.

To Trask (1993:38) 'causative' is a term used to refer to a transitive construction, related to a second simple transitive or intransitive construction from which it differs by the additional presence of an agent NP perceived as the instigator of the action expressed in the simpler construction. Trask cites the following examples where categories (b) are causatives whereas categories (a) are non-causative.

(3) a. Tim smiles a lot 
b. Lisa makes Tim smile a lot

(4) a. I washed the car

b. Lisa made me wash the car

Categories (a) of (3 and 4) are non-causative, whereas in (b) they are causative because they are made to happen.

Crystal states that some languages like English have affixes which have causative role. He exemplifies -ze, as in modernize ('cause to be modern') and such are established in the morphological structure of such languages to systematically contrast between non-causative and causative use of a verb. For example, the en- prefix attaches to some verbs or adjectives to derive a causative reading (verb) similar to 'make' in (5a), hence to enslave implies 'to make someone a slave' while to en-large (b) implies 'to make something large' (Crystal, 2008; Katamba, 1993). Crystal supports his argument with the following examples:

(5) a. Bill en-slaved the prisoner.

b. Bill en- larged the board.

Generally causatives are categorized into three broad categories on formal grounds. Analytical causatives are syntactic constructions with separate verbs such as make. Morphological causatives are created by processes such as affixation by -en and -ify to the root concerned. Lexical causatives are words like kill, send, and feed etc (Shibatani 1976:1). One basic thing about these categories of causatives is the fact that an NP is specified in the construction as being the participant responsible for causing (or not causing) a given situation.

Van Valin and Lapolla (1997) report evidences of morphological causatives in Tepehua language. 
(6) a. i. doduae

ii. dodua-d

b. i. gare

ii. gara- $\underline{d}$

c. i. mae ii ma- $\underline{\mathrm{d}}$

d. i. visi

ii.visi-nam 'be thirsty'

'make thirsty'

'be cool'

'make cool'

'be happy

'please somebody'

'be sick'

'sicken'

Above, the suffix $-d$ with its allomorph -nam are used to make causatives out of a normal verb implying "to make happen" what is implied by the verbs in Pepehua language.

We have reviewed the general linguistic theory of causative constructions with a special emphasis on morphological causatives, and examined data drawn from a number of languages where this type of phenomenon is attested. A bound morpheme (i.e. an affix) expressing causation and a verbal or adjective root amalgamate to form a single morphological causative (Comrie, 1985b; Baker, 1988; Marantz, 1984). The following section focuses on the Bassa morphological causative constructions; it considers its makeup and derivational pattern. Haspelmath, M. \& D.A. Sims (2010) call it "the transitive" because it is believed to convey a type of causative semantics where the causer of an action is also its agent.

\subsection{Morphological Causative Constructions in Bassa}

Morphological causative formation generally implies combining morphemes forming a morphological unit within 
which the idea of causation is expressed or implied (Anyanwu 2007; Comrie 1985b, \& Spencer, 1991). This type of morphological union deriving the morphological causatives may involve affixes and stems / bases or an amalgamation of the two verbal elements, where one of the verbal elements expresses the idea of causation, whereas the other expresses the effect of the causation, thereby forming a morphological causative verbal complex. A morphological causative means the predicate (which hitherto was non-causative) undergoes some derivational process in order to express causativity, there being no separately expressed predicate of causation.

There are two ways in which causative constructions are formed in Bassa, namely the morphologically derived causative constructions and the syntactically derived ones. However, the morphologically derived causative constructions are more productive in Bassa compared to the syntactically derived ones as can be seen in the data presented below. Two lexical categories form the basis for this grammatical processes namely, verbs and adjectives.

\subsection{Verb-Based Causatives}

The Bassa morphological causative construction is essentially mono-clausal and consists of a verbal or adjectival stem, but it is derived from a syntactically bi-clausal sentence. Morphological causatives originates from analytic causative constructions which comprise of a main clause, containing the bound morpheme -nje 'make/cause' and a complement clause which contains another verb. For example, the verbs kelegeji 'cause to fall', wericinji 'cause to quench', zhingicinje 'cause to wake up' are made up of verb stems and the derived morphological causative morpheme. The verb stems of some of these verbs are not causative verbs inherently, but result from the application of the suffix -nje to the verb stems to derive such causative verbs; this can be illustrated as follows: 
(7) a. Gà- Jére

weci-cinji

Jasà

NOM Jere sleep-PST-CAUS

Jasa

'Jere caused/made Jasa to sleep'

b. Gà- Jére zhin-gìcì-nje úwewe ete NOM name wake-CAUS-PST dog DEM

'Jere caused/made that dog to awake'

c. Bò ẹzhẹ- njẹ àganyẹ áta 3SG lose-PST-CAUS PL-guest DEM

'S/he led the guests astray'
d. Bòganye
$z u$-cinji
ihilwè
guest
drawn-PST-CAUS pot

'The guest caused/made the pot to drawn'

e. Tó hiẹre-cẹnje onono

1PL fly-PST-CAUS bird

'We caused/made the bird to fly'

f. Ėmbisegenì oo kuzhò-congo mianwo mò tùgworozo

PL-teacher HAB kneel-CAUS-PL child of disobedience 'Teachers make/cause disobedient students to kneel down.'

g. máá zarè-cènga mianwọ n’ ùhana uvwúngwavungwà

1SG-HAB cross CAUS PLchild LOC-road morningmorning

'I make/cause the children to cross every morning'

In the foregoing examples, which illustrate morphological causation, the verbal morphemes which have 
been inflected for tense constitute the verb stems. The verb stem in the morphological causative verb is the part that expresses the core meaning and heads the morphological causative verb followed by -nje 'make/cause' which is the causative derivative morpheme that can be modified to assimilate the shape of the verb stem it attaches to (the derivative morpheme has different allomorphs depending on the stem it attaches to, hence in the data above the causativizing morpheme is characterized by different allomorphs each assimilating the phonological shape of the stem). This bound morpheme (njẹ 'make/cause') is a verbal morpheme which expresses the idea of causation.

It is also noteworthy that each morphological causative construction in Bassa has a thematic paraphrase which is always an analytic/syntactic causative construction. This can also be illustrated as follows:

(8) a. Gè- Jere njẹ maa gà- Jasàwoto NOM name do-PST REL NOM name sleep 'Jere caused/made Jasa to sleep'

b. Gà- Wàbarẹ njẹ màa ùwẹwẹ e $\square$ tẹ zhinjẹ NOM name do-PST REL dog Dem wake 'Wabare caused/made that dog wake up'

c. Be njẹ màa bòganyẹ iẹnẹ 3SG do-PST REL guest lost 'S/he caused / made the guest get lost'

d. Bòganyẹ njẹ màa ihilùè $i \quad z w i$ guest do-PST REL pot AGR drawn-PST 'The guest caused/made the pot to drawn'

e. Tẹ njẹe màa onono hiẹrẹè 


\section{PL do-PST REL bird fly}

'We caused/made the bird to fly'

In the two illustrations (7 a-e) and (8a-e), we have shown the presence of the verbal morpheme nje 'make/cause'. In (8), it is an independent morpheme with a stable form all through, but in example (7) it attaches to a verb stem as an affix in order to form a derivative causative. Example (8) is an instance of syntactic causative construction where the causative morpheme stands as an independent verb in the main clause with a complemtizer màa which introduces another clause (an independent clause) making the sentence bi-clausal. This causative verb is the same causativizing bound morpheme that attaches to a verb and adjective bases to form morphological causative verbs. When it does, it becomes variable based on the stem it attaches i.e., it assimilates the phonological shape of the base but when it is use syntactically in a clause as an independent verb, it maintains a stable form. Furthermore, this causativizing morpheme sometimes attaches as a suffix as in examples (7a, d, e, f, \& g) but, other times it attaches as an infix as in examples ( $7 b \& d)$. In (7) for instance, (a, d, e, f) are characterized by a suffixes, hence, the affixes occur rightmost, whereas, in (b \& d) the affixes occur within the root.

The nominative case marker has implication for indicative the subject or agent-like subject. In Bassa, gà- is a nominative morpheme that prefixes a proper noun that is [+human] occurring as the subject and agent of a sentence. It never prefixes a noun phrase that occurs at the object position even when the same nouns are used. It also has different allomorphs based on the proper name it pre-modifies. Hence in example (7) it takes the form $g a ̀$, in $(10 \mathrm{a}, \mathrm{b}, \& \mathrm{c})$ it is represented with a different allomorph (gè). Examples:
(9) a. Gà-Jére
shepi
Làrẹ 
NOM name-SUB take-PST name-OBJ

'Jere took Larẹ'

b. Gà- Jasà kwobẹ Rùnoun

NOM name-SUB see-PST name-OBJ

'Jasa saw Runoun'

c. Gà-zájẹmẹ zeriji Dèní

NOM name-SUB lead-PST name-OBJ

'Zajeme led Deni'

In the foregoing, each sentence contains a transitive verb with two arguments, the external argument (the subject) and the internal argument (the object). The subject noun phrases are prefixed with a nominative case marker gà-. The object noun phrases, though proper names [+human] and have all the features of the subject noun phrases, still they are not prefixed with the nominative case maker gà-

We have the contrast of the phenomenon illustrated in examples (7) where only the subject NP is prefixed with the nominative case marker. The examples in (10) show that both the noun phrases in the sentences are prefixed with gànominative case showing that the set in (10) below are syntactically different from those in $(7,9$ etc) above:

(10) a. Gè-Jére njẹ màa gà- Larẹwècì

NOM name do-PST REL NOM name sleep-PST

'Jere caused/made Lare sleep'

b. Gè-Légei njẹe màa gà-Shẹẹn zhinjẹ

Nom name do-Pst Rel Nom name wake-Pst

'Legèì caused/made Sheen wake up.

c. Gè- Zej njẹ màa gà-Wèbìye yẹ ìyimèyẹ 
NOM name do-PST REL NOM name buy-PST food

'Zeje caused/made Webiye to buy food'

In the examples (10a), Jere, the subject is prefixed with a nominative case marker gà- which is the subject. Làre is also prefixed with a nominative case marker. In (b) Legèi which is the subject NP is prefixed with the nominative case marker gèas well as Shẹen. This point reveals the fact that, though in a morphological causative situation, the constructions appear to be mono-clausal; still they are syntactically bi-clausal in origin (Anyanwu, 2007). In Bassa, only a subject NP is prefixed with a nominative marking affix in a sentence that has two arguments (i.e. the external and internal arguments), but the fact that two arguments are marked with a nominative case marker, where nje stands alone and makes the same sentence to have two clauses shows that the causative construction is originally bi-clausal. Secondly, the number of lexical verbs in a finite clause determines the number of clause(s) in a structure that is not characterized by a serial verb construction. This case is clearly not a situation of serial verb construction, rather, each verb fills the predicate of a finite clause, where the complementizer màa, introduces another clause in the same sentence. Hence in examples ( 7 a-e), it occurs as a verbal morpheme $-n j e$, in (8a-c) this verbal morpheme occurs as an independent verb nje 'make/cause'. This verb can further be exemplified in a non-causative fashion to show that the free morpheme nje is what attaches to verbal or adjective root to derive a causative:

(11) a. Gà- Jére njẹ iñ

NON name do-PST it

'Jere did it' 


\section{b. Gà-Wèbiye njẹ uwe $\square$ \\ NOM name do-PST something}

'Webiye did something'

From the foregoing discussion especially examples (7) it is observable that the causative verbal morpheme -nje amalgamates with both transitive and intransitive verb stems. In examples ( 8 a-e) the same causative verbal morpheme -nje takes a complement clause introduced by a complementizer màa 'that'. Based on the foregoing argument, the causative morpheme $-n j e$ is transitive both in its causative (7a-d, 8a-d) and non-causative use (10 and 11). It is a known fact that intransitive verbs do not subcategorize an internal argument (direct object). Examples:

(12) a. Gà-Jasà weci

NOM name sleep-PST

'Jasa slept'

b. ùwewe zhinje

dog wake

'The dog woke up'

c. ùlwa 'weji

fire quench-PST

'The fire quenched'

d. ihilùè zwi

pot drawn-PST

'The pot drowned'

e. onono hiẹre 
bird fly

'The bird flew'

When the causativizing morpheme attaches to a verb stem that is inherently intransitive such as exemplified in (11) above, such a verb becomes transitivized as exemplified in (7) and repeated below.

(13). a. woto 'sleep' (V) woc-icingo 'sleep' (V)
Gà- Zeyi
weci-cinji
Jasà

NOM name

lay/sleep-CAUS-PST name

'Zeyi caused/made Jasa sleep'

b. İbèle zhin-gìcì-njẹ ùwẹwẹ

cat wake-PST-CAUS dog

'A cat caused/made the dog to wake up'

c. Òshilo werin-cinji ùlwa

rain quench-PST-CAUS fire

'The rain quenched the fire'

d. Gà-Gwoje zeri-cinji Swin

NOM name cross-PST-CAUS name

'Gwoje made/cause Swin to cross'

e. Òfonga zwici-nji ihilùè

flood drawn-PST-CAUS pot

'The flood cause/made the pot to drawn'

\section{f. Bòjala hiẹra-cẹnjẹ onono}

hunter fly-PST-CAUS bird 
'A hunter cause/made the bird to fly'

In (13) where the causativizing morpheme attaches to an intransitive verb, the amalgamation of the transitive verb morpheme -nje with an intransitive non-causative verb stem (which expresses some action or event) allows the transitive feature of the causative morpheme to percolate to the intransitive verb stem. The consequence of this results to a morphological causative complex which becomes a transitivized whole, making it to sub-categorize an internal argument (i.e. an object). The glossing is somewhat inconsistent. ${ }^{i}$

It is also not worthy that when this process occurs and the inherent subject move to the direct object position, though as a causee argent, the applied subject that assumes the subject position and the subject of the derived sentence is focused and becomes the privileged argument. In (12) the privileged arguments which are the subjects and focus of the basic sentence give way for the applied ones. We can present the basic structures for clarity below to observe the pattern of focus. Examples:

(14) a. Gà-Jasà weci

NOM name sleep-PST

'Jasa slept'

b. ùwewe zhinje

dog wake

'The dog woke up'

c. ùlwa 'weji

fire quench-PST

'The fire quenched' 
d. ihilùè zwi

pot drawn-PST

'The pot drowned'

e. onono hiẹre

bird fly

'The bird flew'

The illustrations in (14) which are basic sentences, the subject noun phases are the foci of the sentences. Where the rule of causativization applies and moves the inherent or real subject as in (13), it loses to be the focus of sentence and its status as the privileged argument and these attributes are transferred to the subject of the derived sentence, which is the applied argument.

\subsection{Adjective-Based Causatives}

There is another productive category of causatives in Bassa language which is the category of adjectives suffixed with causative morphemes to derive morphological causative verbs. This process can be illustrated as in:

(15) a. hòlò 'wide' (Adj); hórí-cingò ‘widen' (V)

Gà- Shìn heri-cinji idikẹ étẹ NOM name wide-PST-CAUS shirt DEM

'Shien widen that shirt'

b. vo 'hot' (Adj); vo-ngicingo 'heat' (V)

Gẹ̀-Gèbi bo vo-ngìcìngo meni

Nom name AGRS heat-CAUS water

'Gembi is heating water'

c. lomo 'cold' (Adj) lomi-cingo 'make cold' (V)

Tùlomù to lomi-cingo iyimèyẹ 
cold. weather AGRS cool-CAUS food

'Cool weather makes food get cold'

d. Wumanjẹ 'worse' (Adj) wumẹ-cẹ-njẹ 'worsen

Bòganyẹ áta wume-cẹ-njẹ iñ guest Dem worse-PST-CAUS it

'The guest worsened it'

e. gembi 'big' (Adj) gómbí-cíngò 'increase' (V)

Àguma bo gombì-cìngo udalọ uywáywà

king AGR big-CAUS tax yearly

The kind increases tax every year'

f. iri 'deep' (Adj) iri-cingo 'deepen; (V)

òfọngà iri-cinji urèfù

flood deep-PST-CAUS river

'The flood deepened the river'

g. hweteni (Adj) hwócíngà 'cause to dry' (V)

ùwana wo hwoci-ngo iyi

sun AGR-S dry-CAUS thing

'The sun causes things to dry'

h. 'wogo ‘quench' (Adj) wo-ricin-gò ‘cause to quench' (V)

Mypiala wericingi ùlwa

wind quench-PST-CAUS fire

'The wind quenched the fire'

i. 'nyẹnjẹ ‘old' (Adj) 'nyẹngẹ-cẹnjẹ 'make old' (V)

yẹ̀u 'nyẹ-ngẹcẹ-njẹ abìdà ubwa

child old-CAUS-PST PL-shoe POSS-3SG

'The child got his/her shoes worn out'

All of the stems or roots in the foregoing examples (15)

of the causative verbs are adjectives. This can be exemplified 
in the following non-causative sentences using their adjectival stems:

(16) a. İdikẹ i heri
dress/shirt AGR-S wide
'The dress/shirt is wide'

b. Meni mu vi water AGRS hot 'Water is hot'

c. Ùlwa u 'weji fire AGR quench 'The fire quench'

d. Bọtò ata bọ wọmanjẹ Person Det AGR-S worse 'That person is worse'

e. Bìshi mi gembi father AGR-S big 'My father is big'

f. Ùrefu gaà u heri tébìye river Det AGR-S wide very

'This river is very deep'

g. Ògutu o- Kakwu nyẹnjẹ shorts POSS name old 'Kakwus' shorts are worn out/old'

h. Tùgwunò tu hweteni cloth AGR-S dry 'The cloth is dry' 
In Bassa language, as shown in (16), a sentence can be formed without a verb. A subject agreement marker can be followed by a subject complement, especially an adjective. Hence, in (16) the predicate slot is filled either by an adjective or by subject agreement marker. In Bassa also, the adjective, though is clearly contrastive from the verb, still it functions like verbs by occurring sometimes mutually exclusive in the predicate slot with verbs. As earlier noted, the nominative case marker manifests in different allomorphs depending on where it occurs in the sentence. In (10) above, it takes the form ge because the following vowel sound is an open mid sound /e/.

It is also noteworthy that, (16) typifies the basic sentence. The only subject in each sentence is the focus of the sentences, but as soon as the causativizing affix applies and subcategorizes an additional argument and moves the inherent or initial subject below the predicate, automatically, it becomes the focus of the derived structure and the inherent subject becomes the direct object.

Furthermore, in examples (16a-h), it is observable that the roots to which a causativizing morpheme attaches are adjectives whose process derives transitive verbs. Causativization process usually transitivizes a verb stem. Hence, the derived causatives are transitive verbs which in turn subcategorize internal arguments (direct objects). Consequently, in each of the examples above, i.e. (16) each derived verb sub-categorizes an object as its internal argument resulting in an additional argument. Bassa is not alone in this grammatical process. Anyanwu (2005:103) asserts that the consequence of this union is that the "resultant morphological complex becomes a transitivized whole and therefore can subcategorize an internal argument." in support of this ideal, Payne (1997:176), argues that, it is a morphological process described as a kind of valence increasing operation. 
Finally, whether the root is verbal or adjectival, as soon as the rule of causativization applies, apart from other processes, the derived structure is economized vis-à-vis the basic complex one.

\subsection{Conclusion}

The foregoing study investigates the morphosyntactic processes that derive a causative verb from another verb or adjective simply by attaching a bound morpheme to it, thereby increasing the number of arguments by one to the basic structure. (As earlier stated and exemplified in the foregoing, adjectives behave like verbs and they can fill the predicate alone and inflect like stative verbs without a verb itself.) When this process occurs, it derives a transitive verb from an intransitive one or ditransitive from a transitive one. This grammatical process derives a mono-clausal sentence from a bi-clausal one simply by attaching a causativizing morpheme (suffix or infix) to a verbal or adjectival stem both of which yield a morphological complex and other processes associated with phenomenon.

Causativization in Bassa is very productive in economizing language used, that is, it contracts a complex sentence by deriving a simple or mono-clausal one from a biclausal one. Secondly, when a mono-clausal sentence derives from a bi-clausal one, the agent argument which is the applied argument is focused; hence, it displaces the inherent argument and becomes the subject of the derived sentence and the most privileged syntactic argument as well as the causer argument and the inherent privileged syntactic argument winds up as the undergoer and the causee argument below the predicate.

Furthermore, the implication for this study is, it can stimulate more research in this linguistically scanty area and address the dearth of investigation associated with it. This 
work can be replicated in other languages to study the rich structure of Nigerian, African, and other languages or compare to see the area of convergence or divergence.

Philip Manda Imoh is of the Department of Languages and Linguistics, Nasarawa State University, Keffi

\section{References}

Anyanwu, O.N. (2007). The syntax of Igbo causatives: a minimalist account. Port Harcourt: M \& J Grand Orbit.

Baker, M. (1988). Incorporation: a theory of grammatical function changing. Chicago: Chicago University Press.

Blench, R. and Williamson, (2000) 'Niger Congo' in Heine, B. \& Nurse, D. (eds.) African languages: an introduction. Cambridge: Cambridge University Press.

Comrie, B. (1985b). 'Causative verb formation and other verb deriving morphology' in Shopen, T. (Ed.). Language typology and syntactic description (pp. 30948). Cambridge: Cambridge University Press.

Croizer, D.H. and Blench, R. M. (1992). An index of Nigerian languages $\left(2^{\text {nd }}\right.$ edition) Dallas: SIL.

Crystal, D. (2008). A dictionary of linguistics and phonetics. Oxford: Blackwell.

Haspelmath, M. \& D.A. Sims (2010). Understanding morphology. ( $2^{\text {nd }}$ Edition). London : Hodder

Education.

Katamba, F. (1993). Morphology. London: Macmillan. 
Lyons, J. (1968). Introduction to theoretical linguistics. Cambridge: Cambridge University Press.

Marantz, A. (1984). On grammatical relations: Cambridge: Cambridge University Press.

Mutaka, N. (2000). An introduction to African linguistics. Berlin: Lincon Europa.

National Population Commission (2008) www.webcrawler.com/info.wbcrwl.301/census2008

Payne, T. (1997). Describing morphosyntax: A guide for field linguistics. Cambridge: Cambridge University Press.

Shibatani, M. (1976). The grammar of causative constructions. In Shibatani, M (ed.) Syntax and semantics. New York: Academic Press.

Spencer, A. (1991). Morphological theory: An introduction to word structure in generative grammar.

Oxford: Blackwell.

Trask, R.T. (1993). A dictionary of grammatical linguistics. London and NewYork: Rutledge.

Van Valin, R.D. Jr, and R.J Lapolla (1999). Syntax: Structure, meaning and function. Cambridge: Cambridge University Press.

\footnotetext{
${ }^{i}$ In the foregoing discussion, the inconsistency in the glossing pattern is characterized by the fact that the attachment of these affixes is not consistent. Sometimes it attaches as a suffix whereas other times it attaches as an infix. The glosses for pluralization in Bassa can be quite pervasive as can be observed in the data above.
} 